\title{
Antibacterial Activity of Aqueous Extracts of Anacyclus Pyrethrum (L) Link and Corrigiola Telephiifolia Pourr. From the Middle Atlas Region-Morocco
}

\author{
Daoudi Amine \\ Bammou Mohamed \\ Ibijbijen Jamal \\ Nassiri Laila
}

Laboratory of Soil Microbiology and environment, Department of Biology, Faculty of Sciences 11201 Meknes, Morocco

Doi: 10.19044/esj.2017.v13n33p116 URL:http://dx.doi.org/10.19044/esj.2017.v13n33p116

\begin{abstract}
Aqueous extracts of Corrigiola telephiifolia and Anacyclus pyrethrum were studied in vitro for their antimicrobial properties. These plants were collected from the Central Middle Atlas region. Corrigiola telephiifolia Pourr. and Anacyclus pyrethrum (L.) Link are widely used as a natural drug for the treatment of various infectious diseases.

Phytochemical screening of the plants showed the presence of flavonoids, saponins, tannins, steroids and alkaloids.

The determination of the polyphenols in the aqueous extract of the two plants revealed the presence of significant amounts of polyphenols $(58.5 \pm 0.76 \mathrm{mg}$ equivalent of gallic acid (GEA) per gram of extract for C. telephiifolia, and $97.57 \mathrm{mg}$ equivalent of gallic acid (GEA) per gram of extract of $A$. pyrethrum).

The antimicrobial activity of the aqueous extracts against three bacterial strains was evaluated on the basis of the inhibition zone using the disk diffusion assay. The aqueous extract of Corrigiola telephiifolia is slightly active on E. coli. At a concentration of extract $100 \mu \mathrm{g} \mathrm{mL}-1$, the size of the inhibition zone equal to $9 \pm 0.06 \mathrm{~mm}$. Whereas $S$. aureus, E. coli and $K$. pneumoniae showed a sensitivity to the macerate of Anacyclus pyrethrum at the concentration $100 \mu \mathrm{g} \mathrm{mL}-1$ of extract with an inhibition zone $16.55 \pm 0.6$ $\mathrm{mm}, 14.95 \pm 1.25 \mathrm{~mm}$ and $10.83 \pm 0.96$ respectively.
\end{abstract}

Keywords: Antimicrobial activity, aqueous extract, Aromatic and medicinal plants, Central Middle Atlas, Morocco 


\section{Introduction}

The plants have always been the source of medicines, following the presence of many active ingredients that result from therapeutic properties (Ibn Makhlouf, 2008). The plants should be used with great caution, despite their inoffensive reputations (Jean, 2009).

The plants are rich in a wide variety of secondary metabolites, such as tannins, terpenoids, alkaloids and flavonoids, which derive from antimicrobial properties (Muanda, 2010). However, it was not until the early $20^{\text {th }}$ century that scientists became concerned about it (Yano et al., 2006).

People have explored the nature especially plants in search of new drugs (Dabai et al., 2012). Medicinal plants are a rich source of antimicrobial agents and are widely used in human therapy, veterinary, agriculture, scientific research and countless other fields (Hussain et al., 2012).

Although many plant species have been tested for antimicrobial properties, a large majority have not been adequately assessed (Balandrin et al., 1985). In this context, the antibacterial activity of aqueous extracts of two plant species from the Central Middle Atlas region, namely Corrigiola telephiifolia Pourr. (سر غينة - Serguina) from the family of Caryophylaceae, and Anacyclus pyrethrum (L.) Link ( عقير قرحة - Akir karha) from the Asteraceae. These two plants are widely used in Moroccan traditional medicine for the treatment of several diseases: gastroenteritis, spasms and colic, arthritis and rheumatoid, gum diseases and toothache, pathologies of the respiratory system (Bammou et al., 2015; Nassiri et al., 2016)

The main objective of this work was to screened for the presence of phytochemicals constituents and to determine the antimicrobial capacities of aqueous extracts against two gram negative bacillus strains (Escherichia coli and Klebsiella pneumonia) and a gram positive cocci strain Staphylococcus aureus, respectively responsible for pulmonary, digestive and skin infections.

\section{Material and methods}

\section{Monograph of studied plants}

Anacyclus pyrethrum (L.) Link (Figure 1: a, b)

Botanical situation

- Kingdom : Plantae

- Class : Magnoliopsida

- Order : Asterales

- Family: Asteraceae

- Genre : Anacyclus L.

- Species: Anacyclus pyrethrum (L) Link

- French name: Pyrèthre d'Afrique

- Arabic name: عقير قرحة - Akir karha 

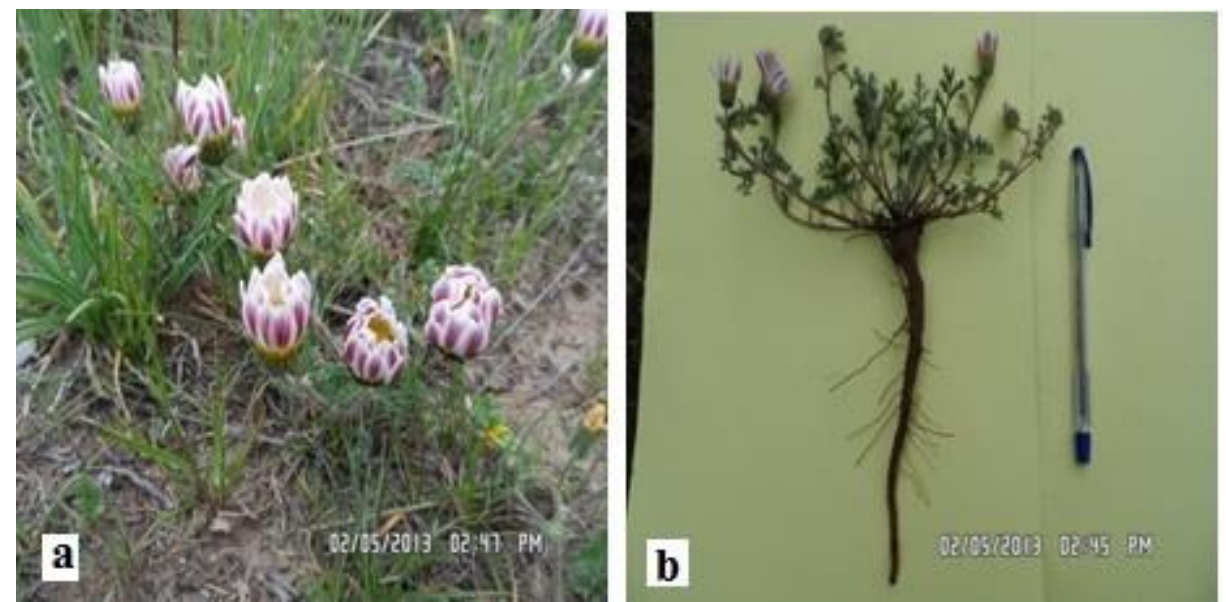

Fig. 1 (a,b): Anacyclus pyrethrum (L.) Link (by DAOUDI Amine)

Botanical description: the diameter of the involucre is between 7 to $22 \mathrm{~mm}$; Bracts on three rows, narrowly triangular, green below, blades above, darkbrown margins, fine, eroded. Hemicryptophyte (spring and summer).

Bioclimate: we can find this plant in the semi-arid, subhumid and humid bioclimate.

Distribution: this species is regularly encountered in High mountains- Atlas Saharan, Anti atlas, High atlas, Middle atlas Moroccan, North atlantic plateaux of eastern Morocco (Jerada) Rif (Chaouene, Jbel Assilenh, valley of Tizi-n-lel) (Fennane et al., 2014).

Traditional use: Anacyclus pyrethrum is widely used for the treatment of some rheumatism; root powder is recommended for internal use against liver disease, decoction is used to treat cases of bronchitis and enuresis (Sijelmassi, 1996; Daoudi et al., 2014; Bammou et al., 2015), and is therefore recommended for treating oral diseases (Bellakhdar, 1997; Daoudi et al., 2014). A. pyrethrum is used in the manufacture of dentifrices (Sijelmassi, 1996).

Toxicity: this plant that cannot be devoid of a toxic part. Indeed, according to a study carried out by Daoudi et al. (2014), several accidents have been reported. It causes respiratory problems, gastroenteritis, colic, skin irritation, mucous membranes, buzzing of the ears and even loss of consciousness (Bellakhdar, 1997; Hmamouchi, 1999).

Plant chemistry: unsaturated amides, inulin, tannins and resin are identified in the root, also alkaloids and yellow dyes are present (Bellakhdar, 1997; Hmamouchi, 1999).

\section{Corrigiola telephiifolia Pourr (Figure 2: a,b)}

Botanical situation

- Kingdom: Plantae

- Class: Magnoliopsida 
- Order: Caryphyllales

- Family: Caryophylaceae

- Genre : Corrigiola L.

- Species : Corrigiola telephiifolia Pourr.

- French name : Corrigiole

- Arabic name : - سر غينة - Serguina

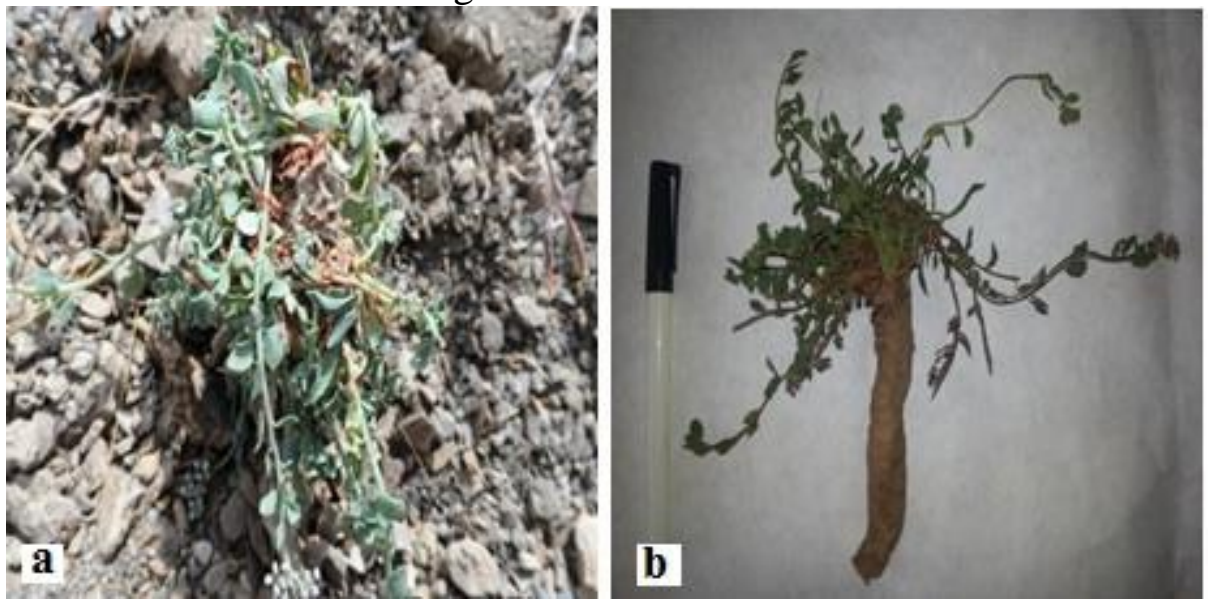

Fig. 2 (a,b): Corrigiola telephiifolia Pourr (by DAOUDI Amine)

Botanical description: Corrigiola telephiifolia is an herbaceous plant. The stem leaves oblong-lanceolate, spatulate or oval, somewhat thick, odorous roots. Inflorescence in axillary and terminal glomeruli. Perianth white or a little pinkish, sensibly as long as the sepals. Five stamens shorter than the petals. Whitish anthers. Three stigmata. Akene trigone, crustacean, included in persistent perianth. Hemicryptophyte (spring and summer).

Distribution: the species is distributed throughout the stoney and sandy plains and mountains: Anti atlas (Siroua), High atlas, Middle atlas, Middle Atlantic, North Atlantic Morocco and Rif (Fennane and Ibn-Tattou, 1999).

Bioclimate: this species is located on the semi-arid soft, semi-arid cold, sub humid bioclimate.

Traditional use: this plant is used to treat, respiratory, gastric, dermatological, urogenital, neurological and typhoid diseases (Daoudi et al., 2015). Also in aromatic; the roots of serghin are widely used in fumigations, they are the reputation of keeping evil geniuses at a distance (Bellakhdar, 1997) this plant is also used against allergies (Juven et al., 1994; El Hafian et al., 2014).

Toxicity: there is no risk of toxicity during administration of this plant, but the dichloromethane extract of this plant showed potent cytotoxicity (Doudach et al., 2012,b).

Plant chemistry: this plant contains many types of secondary metabolites, including terpenes, phenolic compounds, quinones, alkaloids, saponins and 
tannins. The nature and concentration of these compounds depend on the degree of maturity of the plant and the environmental conditions that may influence the capacity of the plant tissue to store and / or synthesis the molecules (Doudach et al., 2012,b).

\section{Preparation of plant material}

\section{Preparation of aqueous extracts}

In this study, we used three modes of traditional extraction: maceration at room temperature, infusion and decoction, the ratio used is $1 / 10(\mathrm{w} / \mathrm{v})$ and the condition was as follows:

The Infusion was prepared by adding $100 \mathrm{~mL}$ of boiling distilled water to the sample powder $(10 \mathrm{~g})$ and were left to stand at room temperature for $15 \mathrm{~min}$, and then filtered through Whatman paper.

The decoction was performed by adding to $100 \mathrm{~mL}$ of distilled water to the powder $(10 \mathrm{~g})$, heated and boiled for $15 \mathrm{~min}$. The mixture was left to stand for $5 \mathrm{~min}$ and then filtered. The infusions and decoctions were evacuated at $40^{\circ} \mathrm{C}$.

The maceration was performed by stirring the plant material powder $(10 \mathrm{~g})$ with $100 \mathrm{~mL}$ of distilled water at room temperature and $150 \mathrm{rpm}$ for 48 $\mathrm{h}$ and filtered through Whatman paper. The combined extracts were then evaporated at $40^{\circ} \mathrm{C}$.

\section{Quantification of active ingredients}

\section{Preliminary phytochemical screening}

The freshly prepared extracts were subjected to standard phytochemical analysis to ensure the presence of following phytoconstituents (Harborn, 1998; Adebayo and Ishola, 2009).

\section{Tests for Alkaloids}

Mayer's Test: Take $5 \mathrm{ml}$ of extract, few drops of Mayer's reagent is added by the side of the test tube. A white creamy precipitate indicates the test as positive.

Dragendorff's Test: Take $5 \mathrm{ml}$ of extract, 1 or $2 \mathrm{ml}$ of Dragendorff's reagent was added. A prominent yellow/orange precipitate indicates the test as positive.

\section{Test for Saponins}

For detection of Saponins the plant extract was subjected for frothing test, $5 \mathrm{ml}$ of the extract is vigorously shaken with $8 \mathrm{ml}$ of distilled water in a test tube for $30 \mathrm{sec}$ and was left undisturbed for $20 \mathrm{~min}$. Persistent froth indicating the presence of saponins. 


\section{Detection of Tannins}

For detection of tannins $3 \mathrm{ml}$ of extract was added to $1 \%$ of lead acetate, formation of yellow precipitate indicates the presence of tannins and in the same way $3 \mathrm{ml}$ of extract was treated with $3 \mathrm{ml}$ of $\mathrm{FeCl} 3$ appearance of green color indicates the presence of condensed tannins.

\section{Detection of Anthocyanins}

For detection of Anthocyanins $3 \mathrm{ml}$ of extract was treated with $3 \mathrm{ml}$ of $2 \mathrm{~N} \mathrm{HCl} \& \mathrm{NH}_{3}$ resulting in to the appearance of pink red colour which turns in to blue violet indicating the presence of Anthocyanins.

\section{Detection of Steroids}

For detection of steroids $0.5 \mathrm{ml}$ of extract was dissolved in $5 \mathrm{ml}$ of chloroform to this mixture concentrated sulphuric acid was added from the side of the test tubes uppe layer at surface appeared red and acidic layer showed yellow with green fluorescence indicating the presence of steroids.

\section{Detection of Flavonoids}

For detection of flavonoids, alkaline reagent test was performed. The extract was treated with $10 \%$ of $\mathrm{NaOH}$ solution resulting in to the formation of deep yellow color indicated the presence of flavonoids

\section{Determination of total polyphenols}

The polyphenol content was measured using the Folin-Ciocalteu method: $1 \mathrm{~mL}$ of Folin reagent (diluted 10 times) was added to $200 \mu \mathrm{l}$ of aqueous extract and $2 \mathrm{~mL}$ of distilled water. The mixture was then in incubation for 4 min before adding $0.8 \mathrm{~mL}$ of sodium carbonate $(7.5 \%)$. The total polyphenols contents were determined after $2 \mathrm{~h}$ of incubation and the absorbance was measured at $\lambda_{\max }=765$ nanometres. The results were obtained as milligram of gallic acid equivalent (GEA) per gram of extract (Ghedadba et al., 2015).

\section{Antibacterial activity by the disk method \\ Bacterial culture}

In order to test the antibacterial potential of aqueous extracts of: Corrigiola telephiifolia Pourr., and Anacyclus pyrethrum (L) Link. Two Gram-negative bacillus strains (Escherichia Coli and Klebsiella pneumonia) and a gram-positive cocci strain Staphylococcus aureus, respectively responsible for pulmonary, digestive and cutaneous infections, were used in this test. These strains were isolated and identified by the bacteriology department, Mohamed V Meknes hospital centre. One to two colonies were isolated from each fresh culture strain and transferred to tubes containing 
sterile distilled water in order to have an initial cell density or turbidity close to that of McFarland 0, $5\left(10^{6} \mathrm{CFU} \mathrm{mL}^{-1}\right)$.

\section{Preparation of the antibiogram}

In the present test, the diffusion technique on agar media was used. Dishes containing Mueller Hinton medium were seeded with $100 \mu$ of each pre-prepared bacterial culture. In each dish corresponding to a strain tested, sterile disks of Whatman paper with a diameter of $6 \mathrm{~mm}$ were deposited aseptically and impregnated with concentrations ranging from $25 \mu \mathrm{g} \mathrm{mL}{ }^{-1}$ to $125 \mu \mathrm{g} \mathrm{mL} \mathrm{m}^{-1}$ of each aqueous extract. In addition, sterile distilled water was used as a negative control.

Finally, gentamicin (30 $\mu \mathrm{g})$ was used as a positive control for Escherichia coli and Klebsiella pneumonia whereas Amikacin (10 $\mu \mathrm{g})$ was the positive control for Staphylococcus aureus. The dishes were made in triplicate and incubated at $37{ }^{\circ} \mathrm{C}$. for 24 hours. The objective of the antibiogram is to predict the susceptibility of a microorganism to one or more antibiotics. This sensitivity is expressed by the appearance of a zone of inhibition around the disks. The results of the antimicrobial evaluation of our extracts are reported in millimeters of the zones or diameters of inhibitions, indicating that the microorganisms are inhibited by the extracts tested.

\section{Reading the results}

The antibacterial activity is manifested by the appearance of a halo of inhibition of the bacterial growth around the disks impregnated with the aqueous extract. The result of this activity is expressed by the diameter of the inhibition zone (mm) (Djenane et al., 2012).

- $\emptyset<8 \mathrm{~mm}$ : non-sensitive bacteria;

- $9<\varnothing<14$ mm: sensitive bacteria;

- $15<\emptyset<19$ mm: very sensitive bacteria;

- $\emptyset>20 \mathrm{~mm}$ : extremely sensitive bacteria.

\section{Results and discussion}

\section{Determination of polyphenols}

Corrigiola telephiifolia Pourr.

Phytochemical screening of the plants revealed some differences in the constituents of the two plants tested. As indicated in Table 1, the powder of Corrigiola telephiifolia Pourr. showed the presence of alkaloids and flavonoids. In addition to the relatively average amounts of tannin and steroids. The demonstration of saponin was remarkable, so the height of the foam was clearly visible. Our results corroborate those found by (Timite, 2012), which showed that species belonging to the family Caryophyllaceae 
Table 1: Phytochemical constituents of Corrigiola telephiifolia and Anacyclus pyrethrum

\begin{tabular}{|c|c|c|}
\hline Test & Corrigiola telephiifolia & Anacyclus pyrethrum \\
\hline Tannins & ++ & + \\
\hline Flavonoids & + & + \\
\hline Alkaloids & + & +++ \\
\hline Saponins & +++ & ++ \\
\hline Steroids & ++ & - \\
\hline Anthocyanins & - & - \\
\hline \multicolumn{2}{|c|}{} & moderate amount + = trace amount $;-=$ completely absent. \\
\hline
\end{tabular}

are often rich in saponin and mainly triterpenic saponin. Finally, Corrigiola telephiifolia Pourr. is very rich in sterols and triterpenes.

The aqueous extracts of the plant are obtained via the three traditional extraction methods; infusion, decoction and maceration. However, the total polyphenols are assayed via the Folin-ciocalteu method. This method is widely studied because it is standardized, simple, reproducible and the interference with the sample matrix which is often colored is minimized at the long absorption wavelength $(765 \mathrm{~nm})$ used (Boukri, 2014). The results showed that the highest concentrations are observed in the macerate of Corrigiola telephiifolia with $58.5 \mathrm{mg}$ of gallic acid / g of extract (Figure 3).

In general, the results of phytochemical screening and colorimetric determination revealed the richness of Corrigiola telephiifolia Pourr. In total polyphenols this oriented us to evaluate the antimicrobial effect of the plant.

\section{Anacyclus pyrethrum (L.) Link}

The phytochemical examination carried out on the ground root extracts of Anacyclus pyrethrum (L) Link. revealed the presence of alkaloids, flavonoids, tannins and saponin, these results being consistent with that of (Elazzouzi et al., 2014). The bibliography indicates the presence in the roots of polyacetylenes compounds and lignans. The roots mainly accumulate alkamides, especially pellitorin, the main constituent of which is found in the roots of $A$. pyrethrum. These nitrogenous and unsaturated substances are associated with the long-known sialagogue effect (Hamimed, 2009). The determination of the polyphenols in the various aqueous extracts (maceration, decoction and infusion) of this plant revealed that the maceration had the equivalent amount of gallic acid in mg per $1 \mathrm{~g}$ of the largest extract relative to the other extracts $(97,57 \mathrm{Qt}$ eq $\mathrm{Ag} \mathrm{mg} / 1 \mathrm{~g}$ extract) (Figure 3). 


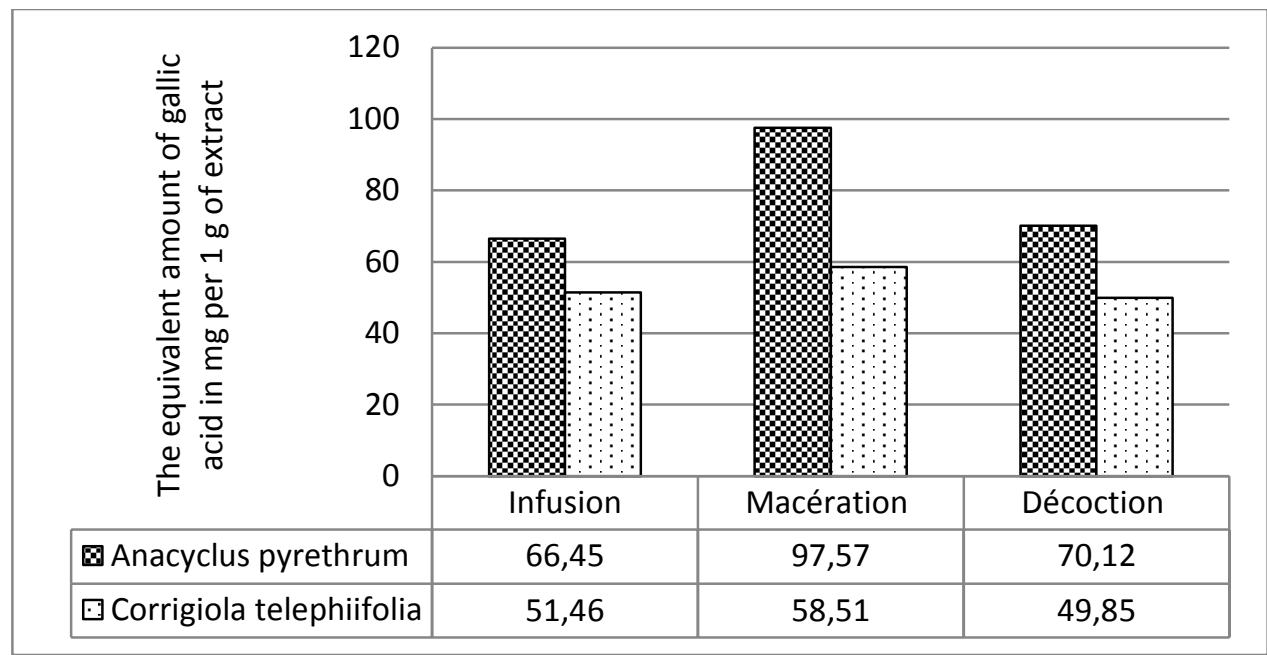

Fig. 3: Determination of polyphenols from aqueous plant extracts

\section{Antibacterial activity of aqueous extracts}

The antibacterial activity of aqueous extracts of Corrigiola telephiifolia Pourr. is tested against three bacterial strains (Escherichia coli, Klebsiella pneumoniae and Staphylococcus aureus), the results revealed that the macerate of the plant is only slightly active against $E$. coli with an inhibition zone of $9 \pm 0.06 \mathrm{~mm}$ at an extract concentration of $100 \mu \mathrm{g} / \mathrm{ml}$ (Table 2).

Table 2: Antibacterial activity of aqueous extract of Corrigiola telephiifolia Pourr.

\begin{tabular}{|c|c|c|c|c|}
\hline \multicolumn{5}{|c|}{ Extract $(100 \mathrm{ug} / \mathrm{ml})$} \\
\hline Germs & ATB & Decoction & Infusion & Maceration \\
\hline S. aureus & $\mathrm{AK}(\mathrm{S})=19$ & - & - & - \\
\hline E. coli & $\mathrm{GN}(\mathrm{S})=20$ & - & - & $9.00 \pm 0.06$ \\
\hline K. pneumoniae & $\mathrm{GN}(\mathrm{S})=20$ & - & - & - \\
\hline \multicolumn{6}{|}{ (-): No zone of inhibition observed: germ insensitive to the extract. } \\
Average of the inhibition diameters in millimeters \\
\hline
\end{tabular}

This inhibiting power may be explained by the abundance of saponin. Thus, it is reported in other studies (Saihi, 2011; Doudach et al., 2013c) that the extract of $C$. telephiifolia is active against $E$. coli. These findings are also confirmed by the results of our ethnobotanical investigation, which showed that the roots of $C$. telephiifolia are recommended to treat digestive infections.

The relatively high values of polyphenols led us to carry out tests on bacterial strains to unveil the antibacterial activity of this plant. S. aureus, E. coli and $K$. pneumoniae showed sensitivity to macerate of Anacyclus pyrethrum at a concentration of $100 \mu \mathrm{g} \mathrm{mL}^{-1}$ with an area of inhibition of $16.55 \pm 0.60 \mathrm{~mm}, 14.95 \pm 1.25 \mathrm{~mm}$ and $10.83 \pm 0.96 \mathrm{~mm}$ respectively (Table 
3). These results were consistent with those published by (Doudach et al., 2012a ; Elazzouzi et al., 2014).

The aqueous extract of Anacyclus pyrethrum produces antibacterial effects on other bacterial strains, namely Listeria monocytogenes and Candida albicans (Selles et al., 2012). These results prove that this plant produces an important antibiotic potential, which seems to correlate well with the total phenolic values found. Therefore, these results provide a good basis for further examination of the possible application of A. pyrethrum for medicinal purposes, as well as in the pharmaceutical industry.

\begin{tabular}{|c|c|c|c|c|}
\hline \multicolumn{5}{|c|}{ Table 3: Antibacterial activity of aqueous extract of Anacyclus pyrethrum (L.) Link } \\
\hline Bacteria & $\mathrm{ATB}$ & Decoction & Infusion & Maceration \\
\hline S. aureus & $\mathrm{AK}(\mathrm{S})=19$ & $10.60 \pm 0.35$ & $6.86 \pm 0.77$ & $16.55 \pm 0.60$ \\
\hline E. coli & $\mathrm{GN}(\mathrm{S})=20$ & $9.33 \pm 0.96$ & - & $14.95 \pm 1.25$ \\
\hline K. pneumoniae & $\mathrm{GN}(\mathrm{S})=20$ & $7.20 \pm 1.00$ & - & $10.83 \pm 0.96$ \\
\hline \multicolumn{6}{|c|}{ (-) : No zone of inhibition observed: germ insensitive to the extract. } \\
Average of the inhibition diameters in millimeters \\
\hline
\end{tabular}

\section{Conclusion}

This work made it possible to demonstrate the antibacterial properties of the aqueous extracts of Corrigiola telephiifolia Pourr. (سر غينة - Serguina) and Anacyclus pyrethrum (L.) Link (عقير قرحة - Akir karha), significant inhibition diameters on pathogens and sometimes resistant to antibiotics.

The results of this work could justify certain traditional uses of these plants in certain pathologies such as respiratory, gastric and dermatological, urogenital, neurological affections. However, this work must continue in order to isolate separately the active ingredients responsible for the antibacterial activity.

\section{References:}

1. Adebayo EA, Ishola OR. Phytochemical and antimicrobial screening of crude extracts of Terminalia gaucescens; Afr. J. Pharm. Pharmacol., 2009; 3: 217-221.

2. Balandrin MF, Klocke JA, Wurtele ES, Bollinger WH. Natural plant chemicals: sources of industrial and medicinal materials, Science, 1985; 228: 1154-1160.

3. Bammou M, Daoudi A, Sellam K, El Rhaffari L, Ibijbijen J, Nassiri L. Ethnobotanical Survey of Asteraceae Family used in MeknesTafilalet Region (Morocco). International Journal of Innovation and Applied Studies, 2015; 13:789-815. 
4. Bellakhdar J. 1997. La pharmacopée marocaine traditionnelle. Médecine arabe ancienne et savoirs populaires. Editions Le Fennec, Ibis Press, Casablanca, Maroc.

5. Boukri NEH. 2014. Contribution à l'étude phytochimique des extraits bruts des épices contenus dans le mélange Ras-el-hanout: Kasdi merbah, Ouargla 99 p.

6. Dabai Y, Kawo A, Aliyu R. Phytochemical screening and antibacterial activity of the leaf and root extracts of Senna italica, Afr. J. Pharm. Pharmacol., 2012, 6: 914-918.

7. Daoudi A, Bammou M, Zarkani S, Slimani I, Ibijbijen J, Nassiri L. Étude ethnobotanique de la flore médicinale dans la commune rurale d'aguelmouss province de khénifra (Maroc). Phytothérapie, 2015; 13:1-9.

8. Daoudi A, Nassiri L, Ibijbijen J, Boukil A. Etude ethnobotanique du Pyrèthre d'Afrique " Anacyclus pyrethrum L." dans le cercle Meknès, El Hajeb, Khénifra, Azrou et Ifrane -Maroc-. ScienceLib, 2014; 6:26.

9. Djenane D, Yangüela J, Derriche F, Bouarab L, Roncales P. Utilisation des composés de feuilles d'olivier comme agents antimicrobiens; application pour la conservation de la viande fraîche de dinde. Nature and Technology, $2012 ; 7: 53$.

10. Doudach L, Meddah B, Alnamer R, Chibani F, Cherrah Y. In vitro antibacterial activity of the methanolic and aqueous extracts of Anacyclus pyrethrum used in Moroccan traditional medicine. Int $\mathbf{J}$ Pharm Pharm Sci, 2012a; 4:402-405.

11. Doudach L, Meddah B, Alnamer R, Faouzi M, Chibani F, Abdelhakim E, Cherrah Y. In vitro Antibacterial Potential Activity of the Methanolic and Aqueous Extracts of Corrigiola telephiifolia Pourr. and Mesembryanthemum nodiflorum. Journal of Biologically Active Products from Nature, 2012b; 2:284-291.

12. Doudach L, Meddah B, Faouzi M, Khatib A, Lalou C, Hammani h, El Omri A, Cherrah Y. Cytotoxic and antioxidant activity of various extracts of Corrigiola telephiifolia pourr. Int. J. Pharm. Pharm. Sci., 2013c; 5:154-158.

13. El Hafian M, Benlandini N, Elyacoubi H, Zidane L, Rochdi A. Étude floristique et ethnobotanique des plantes médicinales utilisées au niveau de la préfecture d'Agadir-Ida-Outanane (Maroc). J. Appl. Biosci., 2014; 81:7198-7213.

14. Elazzouzi H, Soro A, Elhilali F, Bentayeb A, El Belghiti MA, Zair T. Phytochemical study of Anacyclus pyrethrum (L.) of Middle Atlas (Morocco), and in vitro study of antibacterial activity of Pyrethrum. Adv. Nat. App. Sci., 2014; 8:131-141. 
15. Fennane M, Ibn-Tattou M. 1999. Flore pratique du Maroc. Vol. 1. Pteridophyta, Gymnospermae, Angiospermae (LauraceaeNeuradaceae): Inst. Scientifique, Maroc.

16. Fennane M, Ibn-Tattou M, El oualidi J. 2014. Flore pratique du Maroc. Vol. 3. Dicotyledones, Monocotyledones: Inst. Scientifique, Maroc.

17. Ghedadba N, Hambaba L, Ayachi A, Aberkane M, Bousselsela H, Oueld-Mokhtar S. Polyphénols totaux, activités antioxydante et antimicrobienne des extraits des feuilles de Marrubium deserti de Noé. Phytothérapie, 2015; 13:118-129.

18. Hamimed S. 2009. Caractérisation chimique des principes à effet antidermatophyte des racines d'Anacyclus pyrethrum L: Mentouri Constantine $166 \mathrm{p}$.

19. Harborne J.B. 1998. Phytochemical methods. A Guide to modern techniques of plant analysis. $3^{\text {rd }}$ ed., Chapman and Hall Int., New York.

20. Hmamouchi M. 1999. Les plantes médicinales et aromatiques Marocaines : utilisation, biologie, écologie, chimie, pharmacologie, toxicologie, lexiques. Imprimerie de Fédala, Mohammedia, Maroc.

21. Hussain I, Khader JA, Noor S, Ullah R, Talha M, Ahmed M. Study on the medicinal plant Calandula officinalis, Afr. J. Pharm. Pharmacol., 2012; 6 : 973-978.

22. Ibn Makhlouf L. 2008. De la plante au médicament: une passerelle entre tradition et science, Édition Lawne, Maroc. 92 p.

23. Jean B. 2009. Pharmacognosie, phytochimie, plantes médicinales (4 ${ }^{\mathrm{eme}}$ ed.). édition: Lavoisier. $1271 \mathrm{p}$.

24. Juven B, Kanner J, Schved F, Weisslowicz H. Factors that interact with the antibacterial action of thyme essential oil and its active constituents. J. Appl. Microbiol., 1994; 76:626-631.

25. Muanda FN. 2010. Identification de polyphénols, évaluation de leur activité antioxydante et étude de leurs propriétés biologiques [Doctorat]: Université Paul Verlaine-Metz, France, 295 p.

26. Nassiri L, Zarkani S, Daoudi A, Bammou M, Ibijbijen J. Contribution à l'élaboration d'un catalogue ethnobotanique de la commune rurale d'Aguelmous - province de Khenifra - Maroc. International Journal of Innovation and Applied Studies. 2016; 17 : 373-387.

27. Saihi R. 2011. Etude phytochimique extraction des produits actifs de la plante Artemisia campestris de la région de Djelfa: Mise en évidence de l'activité biologique [Doctorat]: Université Ahmed Ben Bella d'Oran 1 Es Senia. Algerie, 83 p. 
28. Selles C, Dib MEA, Allali H, Tabti B. Evaluation of antimicrobial and antioxidant activities of solvent extracts of Anacyclus pyrethrum L., from Algeria. Med. J.Chem., 2012; 2:408-415.

29. Sijelmassi A. 1996. Les plantes médicinales du Maroc. Casablanca, Morocco: Editions Le Fennec 285p.

30. Timite G. 2012. Isolement et caractérisation des saponosides de plantes de la famille des Alliaceae, Caryophyllaceae et Polygalaceae, et évaluation de leurs activités cytotoxiques sur cellules tumorales: Université de Bourgogne. $323 \mathrm{p}$.

31. Yano Y, Satomi M, Oikawa H. Antimicrobial effect of spices and herbs on Vibrio parahaemolyticus. Int. J. Food. Microbiol., 2006; 111:6-11. 